\title{
Issues and Data Needs for GATT Negotiations on Services
}

\author{
Robert M. Stern and Bernard M. Hoekman
}

$\mathfrak{I}$ ARGELY as a result of the initiative of the United States, services have been given a prominent place on the international policy agenda. This was demonstrated in September 1986 at the ministerial meeting of the member countries of the General Agreement on Tariffs and Trade (GATT), held in Punta del Este, when a decision was made to include services in the new round of multilateral trade negotiations. In preparing for the talks, to be known as the Uruguay Round negotiations, it is important (i) to identify the critical analytical and policy issues that are likely to surface in the area of trade in services, (ii) to determine whether sufficient data exist in the United States, and elsewhere, to permit the requisite analysis and (iii) to identify the main gaps in the existing data and assess what can and needs to be done to close these gaps both for analytical purposes and for the successful conduct of the negotiations. This article discusses the three matters. 1

\section{CRITICAL ANALYTICAL AND POLICY ISSUES}

This section begins by discussing some distinguishing characteristics of goods and services and goes on to consider a typology of services which will provide the framework for the discussion of analytical and policy issues and data needs. ${ }^{2}$

\section{Distinguishing Characteristics of Services}

In an insightful article in the December 1977 number of the Review of Income and Wealth, the British economist T.P. Hill makes the following distinction between goods and services: ${ }^{3}$

ROBERT M. STERN is Professor of Economics and Public Policy, and a member of the staff of the Institute of Public Policy Studies, at the University of Michigan, Ann Arbor, in the United States of America, where BERNARD M. HOEKMAN is a research fellow. They are co-authors, with John H. Jackson, of An Assessment of the GATT Codes on Non-tariff Measures (1987). Professor Stern is co-author, with Alan V. Deardorff, of The Michigan Model of World Production and Trade (1986) and editor of US Trade Policies in a Changing World Economy (1987). 
'A good may be defined as a physical object which is appropriable and, therefore, transferable between economic units. .

'A service may be defined as a change in the condition of a person, or of a good belonging to some economic unit, which is brought about as the result of the activity of some other economic unit. . . This definition . . . is consistent with the underlying idea which is inherent in the concept of a service, namely that one economic unit performs some activity for the benefit of another. . Whatever the producer of the service does must impinge directly on the consumer in such a way as to change the condition of the latter. Otherwise, no service is actually provided.'

It seems clear from these definitions and from actual experience that service activities are numerous and diverse both in themselves and in the change that they effect in goods and persons. Three distinctions can usually be made between goods and services: (i) production and consumption of services have to take place simultaneously, (ii) services cannot be stored and (iii) services are intangible. Although we will return to the empirical problem of how to distinguish a service from a good, we will not address definitional questions in detail. ${ }^{4}$

For the purposes of analysis and discussion, it is useful to consider a typology of the way in which services may be provided internationally. This typology is based on whether the movement of the provider and demander of the service is required between countries. This focus on mobility allows issues in services to be addressed in the context of international trade theory. We distinguish four types of services. (Each type can be further divided by distinguishing services that are related to goods from services that are independent of goods.)

1. No movement of providers or demanders ('separated' services): This terminology of 'separated' services, attributed to the Australian economists Gary Sampson and Richard Snape ${ }^{5}$ is analogous to what Jagdish Bhagwati has called 'disembodied' or 'long distance' services. ' They can be considered to be "pure' or independent services insofar as they can in principle be traded just like goods, without there being any necessity for a foreign presence. Many of these services are complementary to trade in goods.

2. Movement of providers only (demander-located services): In this case, physical proximity is a necessary condition for the service; and capital and/or labour must move internationally for provision to be feasible. Thus there may be foreign direct investment involving movement of physical or financial capital and/or movement of skilled or unskilled labour. But there need not be complete movement of all factors in providing the services. There may be an 'absent' factor, say management, which resides in the home country, but nonetheless can supply its services 'telematically' to augment factors of production located abroad. ' This is a case, therefore, of 'separated factors' as opposed to the separated services discussed in case 1 . Thus, by means of 
international movement, factors (separated or not) may provide services in the foreign production of goods or other services.

3. Movement of demanders only (provider-located services): Here the services are provided in the country in which providers are physically located. Prime examples are tourism, education and medical services.

4. Movement of providers and demanders (footloose, non-separated services): This case is included for the sake of completeness. It corresponds to a situation in which factors of production and consumers both move to another country where some service is then performed. Services provided by absent factors may be relevant here as well.

It should be noted that the relationship between goods and services is often important when analyzing the significance of international exchange of services and the expected effects of liberalizing barriers to trade in goods and/or services. In general, services are complementary to trade in goods (for example, transport or insurance), or a substitute for trade in goods (franchising or leasing), or unrelated to goods (life insurance, tourism or professional services). ${ }^{8}$ In practice, many services are embodied in goods and thus change the condition of goods. The question naturally arises, then, as to whether it is analytically meaningful and practical to separate the two. The answer depends on the nature of technological change and the ways in which the specialized activities of firms, to use Professor Bhagwati's terminology, are 'splintered' off into services from goods and goods from services." Thus, depending on the level of aggregation for recording transactions and particularly the time span involved, it may be quite difficult to distinguish goods from services and vice versa at the industry level.

This difficulty will become more pronounced, especially if services that previously were purchased at arm's length from other firms are subsumed within the firm. The reason is that intra-firm transactions often cannot be measured accurately because there is no direct market analogue available to value them. Given the size and complexities of most large corporations, in terms of both their domestic and multinational activities, it seems unlikely that it will ever be possible to identify separately the services embodied in goods within the firm. Thus the changing relative importance of inter-firm and intra-firm transactions will have a major impact on the measurement of the values of goods and services.

Inherent difficulties in distinguishing goods and services include (i) the joint sales of goods and services (for example, a restaurant meal or the sale of a durable good together with a warranty), (ii) intra-firm performance of services (for example, legal and accounting work), (iii) tangible outputs which may serve as media for the delivery of intangible outputs (for example, gramophone records and cinematograph films) and (iv) differences in packaging or delivery (for example, a storage battery or direct purchase of electricity from a public utility). ${ }^{10}$

The focus on whether the movement of the providers and demanders of services is required is especially pertinent in analyzing the relationship between trade and 
international factor movements involving the provision of services. Thus in case 1 , with separated services, there can be international trade in services, but there is no need for any foreign direct investment or movement of labour. In cases 2 and 4 the provision of services requires a foreign presence and hence there will be foreign direct investment and/or the movement of labour internationally (telematic or physical). In case 3, with only demanders moving, there may be trade in transport - a separated service - in addition to the expenditure on goods and provider-located services.

The preceding discussion suggests a need to clarify what is meant by 'trade in services'. We define it as occurring when domestic factors receive income from non-residents in exchange for their services. Where the service is performed is not relevant. Our definition of trade in services is therefore much broader than the conventional one which usually refers only to separated services. That is to say, in addition to separated services (case 1), we include provider-located services (case 3 ) and demander-located services (cases 2 and 4) insofar as domestic factors receive payments from non-residents. If demander-located services are provided by a foreign affiliate that employs only local factors, trade in services will not have occurred. This seems rather unlikely, however, since foreign affiliates will usually obtain some inputs from the parent company which means that there will in fact be trade in services. How large this trade will be depends on the particular circumstances.

\section{Comparative Advantage and the Gains from Trade and Factor Mobility in Services}

The principle of comparative advantage is at the basis of any exchange across borders of goods and presumably services as well. Comparative advantage is also relevant to the international mobility of labour and capital. Elsewhere, we concluded, using the standard competitive framework, that comparative advantage was applicable to each of the cases noted in our typology of services. ${ }^{11} \mathrm{We}$ saw no reason to alter our conclusion even when various economic and noneconomic distortions were taken into account. That is to say, the conditions for intervention and the choice of optimal policies are generally well defined for the different distortions; and service industries do not appear, in themselves, to raise new problems.

It is interesting, even so, as Brian Hindley and Alasdair Smith have pointed out, that service industries are often prime targets of government intervention and regulation - to a much greater degree than goods-producing industries. ${ }^{12}$ The grounds for government actions generally involve the supposed dangers of destructive competition and the need to protect the interests of buyers who are imperfectly informed, especially when purchasing intangible services. The beneficial experiences with de-regulation in many countries suggest that the dangers of 
destructive competition can be exaggerated. Furthermore, when there are scarcity rents at stake, vested interests may have much to gain by maintaining government regulation. Imperfect information may constitute a genuine problem, but it is not unique to services and, even if it were, it is not clear that the nationality of providers should form the basis of government policy.

Impediments to international trade and factor movements involving services may be due to conscious government policies, but in addition there may be natural barriers which make certain kinds of international transactions relatively costly. For example, the market for some services may be limited spatially because of the need for direct contact between provider and demander. But it is possible that, with technological advances, transaction costs may fall significantly so that the service can be supplied 'long distance', in a separated form rather than by direct contact between provider and consumer. The development of computers and satellites is a case in point. In these circumstances, if there were governmentimposed barriers which required the physical presence of providers, it might become possible to circumvent those barriers by means of the new technology.

The point here is that the presence or absence of government-imposed and natural barriers will have an effect on decisions involving trade and factor movements, especially with respect to the location and mode of provision of the service. This can be illustrated by the various options which may exist for providing architectural design services. Thus an architect could transmit his drawings abroad by electronic means, have a draftsman do the drawings abroad based on instructions transmitted electronically, go to the importer's country of residence and do the drawings there, have the buyer come to the architect's country of residence to obtain the drawings, or meet with the buyer in a third country. The first two options would probably be the most efficient way of providing this service, but government restrictions may necessitate choosing one of the other options. Many other examples could undoubtedly be constructed to illustrate this point. Presumably, if existing barriers were relaxed or removed, the mode of provision and consumption of the service would correspond to the most efficient of the available alternatives.

If it is granted that comparative advantage is applicable to international transactions in services, there is a strong presumption that countries may realize substantial gains from the liberalization of impediments to trade and factor movements related to services. The gains from liberalization arise from more efficient allocation of resources within and between countries, the lowering of prices and the expansion of choices afforded to consumers and firms. The magnitude of the gains from liberalization will depend on whether barriers are to be lowered only on trade in separated services, keeping restrictions on factor movements intact, or whether trade in separated services and factor movements are to be liberalized. This point is important because the complete liberalization of 
both trade and factor movements is rather unlikely to occur in the Uruguay Round negotiations.

\section{Implications for Analysis and Policy}

The preceding discussion is directly relevant to the negotiations on services in the new GATT round. It is beyond the scope of this article to discuss the entire range of issues which may have to be resolved in the course of the talks. Nonetheless, there are some particular issues suggested by the earlier discussion which merit comment and have implications for the discussion of data needs.

1. A crucial issue concerns the definition of what constitutes a trade issue, as opposed to an investment issue, in the context of services. The GATT has traditionally avoided investment-related issues involving goods and many countries believe that this should extend to services. But, as discussed above, foreign direct investment is a precondition for the provision of many services. It thus seems virtually impossible to avoid investment issues in the Uruguay Round talks. Negotiations dealing only with the liberalization of traded services would be beneficial, but they would be far more so if restrictions on factor movements related to services were included. It may be, in cases where countries have important interests in providing, or protecting against, a foreign presence in services, that the incentives to participate in multilateral negotiations would be reduced if investment-related issues were kept off the agenda. This suggests that a potentially important question would be to determine the empirical magnitudes of the various kinds of services identified earlier and the stakes which individual countries might have in particular activities, including the maintenance of impediments to both trade and service-related factor movements.

2. If it can be granted that international trade and factor movements involving services are governed by the conventional economic and policy-related variables determining comparative advantage, this in turn would establish the basis for analyzing empirically the effects on economic welfare of the existing structure of trade and factor mobility in services and possible changes in this structure. This would require documenting the foreign restrictions faced by firms engaged in trade and investment in services in the major trading countries. In this connection, it would be interesting to review the restrictions on services around the world in the light of the models of the political economy of protection and lobbying that have been developed in recent years, in order to determine whether the same considerations apply to services as to goods. ${ }^{13}$ Furthermore, since restrictions on trade and factor movements involving services can be analyzed using the same kind of cost-benefit analysis that is used for goods, it should be possible to determine (i) what effects existing restrictions have on consumers and producers and the return to factors and (ii) how these might change if restrictions were reduced or removed altogether. Data requirements may be an important limiting 
consideration here, but this should not controvert the applicability of determining how economic welfare may be affected in given empirical circumstances.

3. Differences in factor endowments and technology have an important bearing on the relative prices of services and returns to factors in the advanced industrialized and developing countries. It has been observed that many services are relatively more expensive in rich than in poor countries and that the real price of services relative to goods tends to rise with higher levels of per-capita income. ${ }^{14}$ This suggests that some developing countries may have a structural advantage in the provision, especially, of labour-intensive services. If so, it is important to identify the activities involved and to determine the factors, including the removal of impediments, which may be crucial in the efficient expansion of those activities through time. Thus the fortunes of some developing countries may lie in services as well as in goods. The mix between a country's actual and potential comparative advantage in goods and services is obviously important in charting future developments and identifying the interplay of different types of trade restrictions and the possible benefits and costs of different patterns of liberalization.

4. Another interesting question is the relationship between international trade in goods and services. As mentioned above, some services may be complementary to goods, in which case the liberalization of service-related transactions may lead to increased trade in goods. By contrast, in the case where factor mobility substitutes for trade in goods, the liberalization of impediments to trade in services could actually reduce the volume of trade in goods. Related to this is the impact of technical change on the volume and pattern of trade in goods and services. As noted earlier, technical change may result in services changing categories, as in the case of separated services which no longer require physical proximity. Technical change may also result in increased trade in new goods which are 'splintered' off from services and vice versa. ${ }^{15}$ Furthermore, organizational innovations may result in separated services that no longer require a foreign presence. ${ }^{16}$ Multinational enterprises may play a leading role in these developments and, therefore, it would be interesting to analyze the important features in corporate decision making which shape the pattern of intra-firm specialization and the geographical location of foreign subsidiaries providing services. The factors affecting the barriers to entry of competitors and the ability of firms to sustain their competitive edge are also worthy of investigation.

The above list of issues is by no means exhaustive. No doubt others will be able to suggest additional issues that may be worthwhile investigating and that will have implications regarding the requisite data.

\section{DATA NEEDS AND AVAILABILITY}

The foregoing issues raise questions concerning the needs and availability of data on services, to which the article now turns. ${ }^{17}$ Attention is focussed on those 
considerations which are likely to be important in the course of the Uruguay Round negotiations.

\section{Data Needs}

In preparing for GATT negotiations on services, it would be desirable, for reference purposes, to construct a global data base that includes (i) the domestic production of services, (ii) trade in separated services and (iii) services which are provided by foreign firms and foreign labour in individual countries. This would make it possible to assess the importance of services in domestic economies and the value of trade in separated services by major category and country, as well as the value of services produced abroad by a country's multinational enterprises and labour. In addition, information is needed on the existing government-imposed barriers and regulations which may impede traded services and/or the right of establishment of foreign firms and the employment of foreign non-immigrant labour.

The construction of the data base would provide much-needed information on the magnitudes and composition of services in the world economy and it would permit a descriptive analysis of the stakes that particular countries and industries have in the existing structure of trade and the foreign provision of services. Linking the data on services with comparable data on goods would be a logical next step. This would furnish a comprehensive view of the different components of international transactions in both goods and services and, in turn. make it possible to analyze the important interrelationships involved.

In the same vein, it would be desirable to merge the available data for goods and services relating to impediments to trade and to foreign production in order to estimate the expected effects of liberalization. This is bound to be exceptionally difficult, however, since the restrictions affecting scrvices are typically more akin to non-tariff measures than to tariffs. It may not be possible, therefore, to express these non-tariff measures in a standardized form that is susceptible to quantitative analysis, as in the case of tariffs. Of course, this problem also arises for non-tariff measures affecting goods, but at least here the relevant magnitudes of trade by country and industry are known. In the case of services, presumably a first step would be to devise an inventory of the important restrictions. While such an inventory would not reflect how effective are particular restrictions, it would be useful in helping countries to identify which restrictions are believed to affect them adversely and might be the object of negotiations.

Assuming that the reference data on services can be assembled, this would permit analytical background and assessment studies to be conducted. These studies could in principle be oriented towards the kinds of research issues described above. A first step would be to analyze the effects of existing tariffs and 
non-tariff measures on trade and the foreign production of goods and services. The simplest approach would be to use a partial equilibrium analysis focussed on trade only which would require information on the production and trade of given industries, the size of existing barriers and estimates of the relevant elasticities of demand and supply. A more ambitious undertaking would be to imbed this information for all industries in the major developed and developing countries into a general equilibrium framework like the one provided by the model of world production and trade which has been developed at the University of Michigan. ${ }^{18}$ The object in both cases would be to obtain estimates of the trade, employment, price and welfare effects of existing restrictions and to determine how these effects would be altered if the restrictions were reduced or eliminated altogether.

Since a foreign presence is essential for the provision of a wide variety of services and in view of the substantial foreign production of goods as well, the type of analysis just mentioned would have to be extended to take into account international factor mobility. This raises many new complexities which to date have not been addressed systematically in a computational framework. ${ }^{19}$ It is nonetheless essential to think in these broader terms, for otherwise some of the most important relationships and potential effects of the liberalization of restrictions could be overlooked.

Studies of comparative advantage, complementarities and substitution between goods and services, the impact of technical change and the determinants of the behaviour of multinational enterprises and the political economy of restrictions and liberalization would require additional special data to be constructed for each purpose.

Construction of a data base of the type suggested above may not be completely feasible. Indeed, some may consider it to be hopelessly Utopian. Nonetheless, it provides a benchmark for which to aim. On a more practical level, however, there are two issues which need to be addressed in the light of the Uruguay Round negotiations: How adequate are available data for the creation of something like the data base described above? And is such a comprehensive data base really needed in order to conduct successful negotiations? It may well be, for example. that many of the questions which require information of the kind incorporated into an ideal data base may not be crucial for the negotiations themselves. These issues are discussed in the next section. First, however, it may be useful to review briefly the kinds of data which are currently available.

\section{Data Availability}

There are three main sources of data relating to services: (i) national accounts. (ii) balance-of-payments statistics, and (iii) industry-specific information collected by government agencies and/or the private sector. 
The national accounts are the primary source of data on the share of services in gross domestic product (GDP) and employment. For reporting purposes, services are classified according to expenditure on final demand and/or industry of origin. In the former case, intermediate (business) services are not included in final demand. While national accounts data are useful for gaining insight into the relative importance of the services sector in an economy, data on international transactions in services are obtained primarily from a country's balance-ofpayments accounts and, in the United States, from surveys of foreign direct investment. The classification of services found in balance-of-payments accounts is by type of activity and includes both non-factor services (for example, travel, transport and 'other private services') and factor services (for example, royalties and fees and investment income). ${ }^{20}$ The factor services typically do not distinguish income from goods-related investment and service-related investment. Also, workers' remittances are generally included under 'transfers' in the balance-ofpayments accounts, although they are a component of factor services. ${ }^{21}$

TABLE 1

Total World Exports of Services and Merchandise, Investment Income. Workers' Remittances and GDP

\begin{tabular}{|c|c|c|}
\hline & $\begin{array}{c}\text { Value } \\
\text { in } 1984 \\
(\$ \text { billion })\end{array}$ & $\begin{array}{c}\text { Average } \\
\text { annual growth } \\
1970-80 \\
(\%)\end{array}$ \\
\hline Service exports & 357 & 18.7 \\
\hline Merchandise exports & 1.545 & 20.4 \\
\hline Investment income & 244 & 22.4 \\
\hline Workers ${ }^{\circ}$ remittances & 24 & na \\
\hline GDP & 11,891 & 14.2 \\
\hline
\end{tabular}

Sources: Balance of Payments Statistics, International Monetary Fund. Washington, 1985 yearbook. Part 1: US National Study on Trade in Services (Washington: US Government Printing Office, for the Office of the United States Trade Representative, 1983) p. 110; and Worldwide Economic Indicators, Business International Corporation, New York. 1985

Some illustrative data for 1984 and rates of growth for 1970-80 for total world exports of services and merchandise, investment income, workers' remittances and GDP are given in Table 1. The percentage distribution of the major categories of service exports and percentage shares in world service exports for the major industrialized countries for 1980 are presented in Table 2 . While it is not possible to discuss here the details in these tables, they are nevertheless indicative of the information which is available on a global basis for the major balance-of-payments categories. ${ }^{22}$ It is almost certainly the case, however, that balance-of-payments data substantially under-report the importance of the international exchange of services. 
The third important source of data on international transactions in services is based on surveys of foreign direct investment by government agencies or on financial flows monitored by central banks. In the United States there are periodic

TABLE 2

Percentage Distribution and Shares of World Exports of Services for the Major Industrialized Countries. 1980

\begin{tabular}{|c|c|c|c|c|c|c|}
\hline & \multirow[b]{2}{*}{ Shipment } & \multirow{2}{*}{$\begin{array}{l}\text { Other } \\
\text { transport } \\
\text { and } \\
\text { passenger } \\
\text { services }\end{array}$} & \multirow[b]{2}{*}{$\begin{array}{l}\text { Travel } \\
\text { and } \\
\text { tourism }\end{array}$} & \multirow[b]{2}{*}{$\begin{array}{l}\text { Other } \\
\text { private } \\
\text { services }\end{array}$} & \multicolumn{2}{|c|}{ Total } \\
\hline & & & & & $\%$ & $\begin{array}{c}\text { Value } \\
\quad \$ \\
\text { billion) }\end{array}$ \\
\hline & \multicolumn{4}{|c|}{ Percentage distribution } & & \\
\hline United States & 9.9 & 34.5 & 26.8 & 28.8 & 100.0 & 37.5 . \\
\hline Canada & 11.0 & 10.1 & 41.1 & 37.8 & 100.0 & 7.0 \\
\hline Japan & 38.2 & 31.4 & 3.3 & 27.1 & 100.0 & 19.4 \\
\hline United Kingdom & 15.5 & 30.1 & 18.6 & 35.8 & 100.0 & 37.1 \\
\hline France & 4.0 & 32.3 & 25.0 & 38.7 & 100.0 & 33.0 \\
\hline West Germany & 15.6 & 19.3 & 19.4 & 45.7 & 100.0 & 33.8 \\
\hline Italy & 14.2 & 14.6 & 38.0 & 33.2 & 100.0 & 23.5 \\
\hline Netherlands & 19.6 & 38.6 & 9.0 & 32.8 & 100.0 & 18.6 \\
\hline Belgium & 16.1 & 15.3 & 12.2 & 56.4 & 100.0 & 14.9 \\
\hline Switzerland & 4.8 & na & 48.5 & 46.7 & 100.0 & 8.4 \\
\hline Sweden & 22.2 & 23.3 & 12.0 & 42.4 & 100.0 & 8.0 \\
\hline Norway & 54.1 & 22.8 & 8.2 & 14.9 & 100.0 & 9.2 \\
\hline \multirow[t]{2}{*}{25 largest exporters ${ }^{a}$} & 14.5 & 25.4 & 25.8 & 34.4 & 100.0 & \\
\hline & \multicolumn{4}{|c|}{ Percentage shares } & & \\
\hline United States & 7.9 & 15.9 & 12.2 & 9.8 & 11.7 & 37.5 \\
\hline Canada & 1.6 & 0.9 & 3.5 & 2.4 & 2.2 & 7.0 \\
\hline Japan & 16.0 & 7.5 & 0.8 & 4.7 & 6.1 & 19.4 \\
\hline United Kingdom & 12.4 & 13.8 & 8.4 & 12.1 & 11.6 & 37.1 \\
\hline France & 2.8 & 13.2 & 10.0 & 11.6 & 10.3 & 33.0 \\
\hline West Germany & 11.3 & 8.0 & 8.0 & 14.1 & 10.6 & 33.8 \\
\hline Italy & 7.2 & 4.2 & 10.8 & 7.1 & 7.3 & 23.5 \\
\hline Netherlands & 7.8 & 8.8 & 2.0 & 5.6 & 5.8 & 18.6 \\
\hline Belgium & 5.2 & 2.8 & 2.2 & 7.7 & 4.7 & 14.9 \\
\hline Switzerland & 0.9 & na & 5.0 & 3.6 & 2.6 & 8.4 \\
\hline Sweden & 3.8 & 2.3 & 1.2 & 3.1 & 2.5 & 8.0 \\
\hline Norway & 10.7 & 2.6 & 0.9 & 1.2 & 2.9 & 9.2 \\
\hline 25 largest exporters ${ }^{a}$ & 100.0 & 100.0 & 100.0 & 100.0 & 100.0 & \\
\hline Total ( $\$$ billion) & 46.5 & 81.2 & 82.4 & 109.9 & & 320.0 \\
\hline
\end{tabular}

Source: Adapted from US National Study on Trade in Services (Washington: US Government Printing Office, for the Office of the United States Trade Representative, 1983) p. 114.

Based on totals for the 25 largest exporters of services in 1980. 


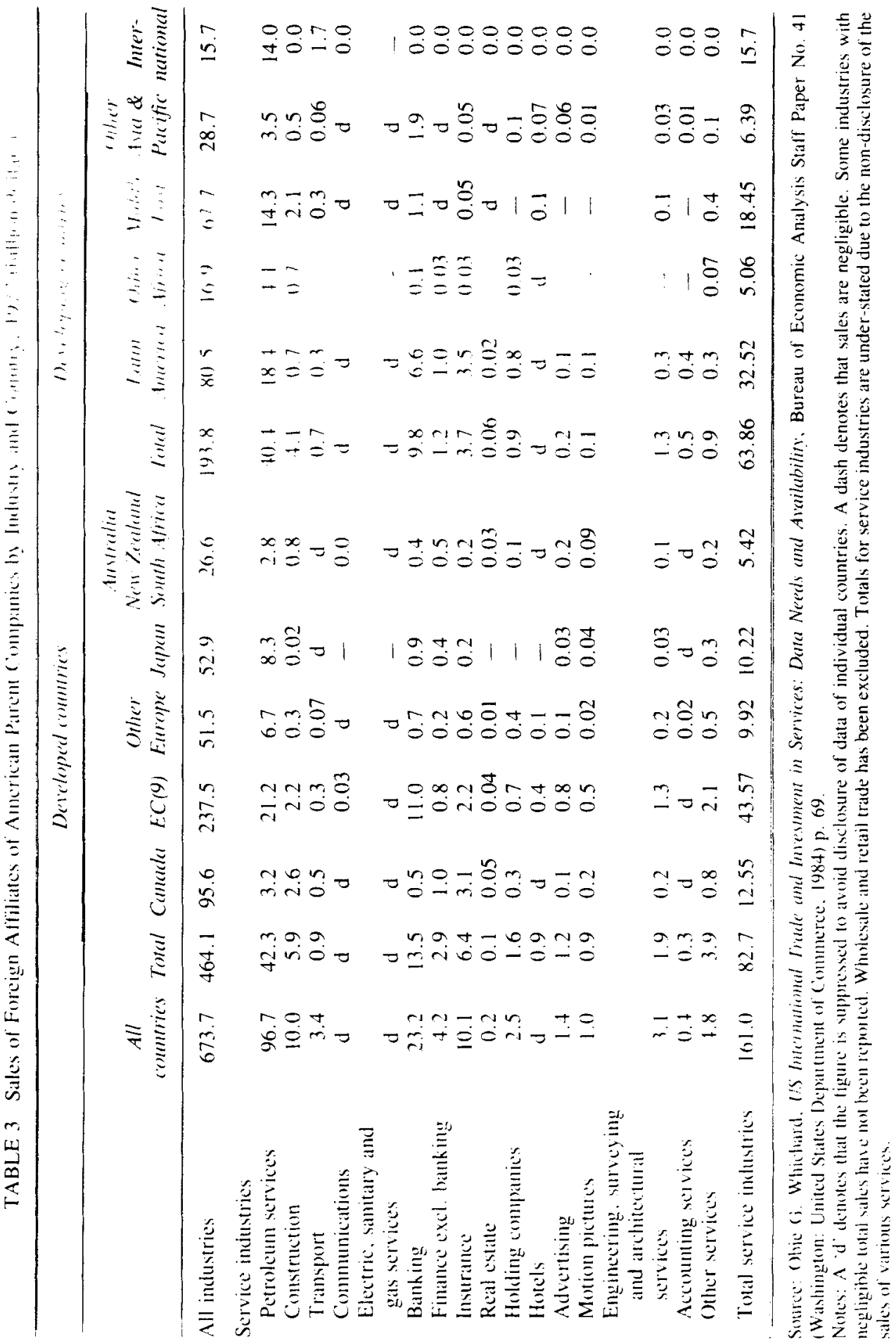


'benchmark' surveys (for example, for 1977 and 1982) and since 1982 there have been annual updates. An indication of the sales of services in 1977 by the foreign affiliates of American parent companies, broken down by country, is given in Table 3. Table 4 combines data on direct sales of goods and services with sales through foreign affiliates for the United States for 1983. There are noteworthy differences between the magnitudes and composition of services that are directly exported (traded) and the services that require the foreign presence of Americanbased firms. The latter are substantially higher in total than the former. Although not too much should be made of this, given the inaccuracy of balance-of-payments data, it is certainly the case that a more comprehensive view of the interests and involvement of the United States could be obtained by merging both types of data in a rigorous fashion. ${ }^{23}$

TABLE 4

Direct Exports and Sales of Goods and Services through Foreign Affiliates of American Parent Companies, 1983 (billion dollars)

\begin{tabular}{lccc}
\hline & Total & Goods & Services \\
\hline Direct exports & 230 & 188 & 42 \\
Sales by majority-owned foreign affiliates & 714 & 646 & 68 \\
To American parents & 68 & 61 & 7 \\
To unaffiliated American persons & 13 & 11 & 2 \\
To other foreign affiliates & 102 & 92 & 10 \\
To unaffiliated foreigners & 531 & 482 & 49 \\
Sales by minority-owned foreign affiliates & 188 & na & na \\
Total sales by foreign affiliates & 902 & na & na \\
\hline
\end{tabular}

Source: Bernard Ascher and Obie G. Whichard, 'Improving Services Trade Data', in The Emergence of the Service Economy (Geneva: Services World Forum, 1987) pp. 46-47.

Besides the 'benchmark' surveys and annual updates in the United States, there are data published by the Bureau of the Census, in the Department of Commerce. But these data are not broken down geographically and the industry classification does not account clearly for services provided as a secondary activity. ${ }^{24}$ Finally, there are studies which have been done for a variety of service industries by official bodies, private organizations and individuals. ${ }^{25}$

In preparing for GATT negotiations on services, it is obviously important to know what are the important barriers that restrict traded services and affect international factor mobility in services. In the case of the United States, this kind of information has been compiled by industry and country, in machine-readable form, by the Office of the United States Trade Representative (USTR), in the Executive Office of the President. Industries covered by the USTR reporting 
system include accounting, advertising, banking, building and construction, data processing, engineering, franchising, hotels and motels, information services, insurance, leasing, legal services, motion pictures, telecommunications, tourism, air transport and maritime transport. The difficulty which arises in using the kind of information being gathered by the USTR is to determine (i) whether all the items listed constitute genuine barriers and, if so, how important are the individual barriers and (ii) whether or not their reduction or removal may be negotiable.

\section{ADEQUACY OF EXISTING DATA}

We now return to the issues posed at the end of the discussion of data needs in the preceding section, namely the adequacy of available data for purposes of constructing an ideal data base and the question of whether a comprehensive data base is necessary for successful GATT negotiations.

\section{Feasibility of Creating a Data Base}

At the minimum, an ideal data base would have to contain information on the value of production and trade for particular service (and goods) industries, estimates of the size of existing barriers and estimates of the relevant elasticities of demand and supply. This information would be needed for services of all four types distinguished in our typology.

Separated services, such as transport, insurance, legal and financial services, should, in principle at least, be captured completely by existing balance-ofpayments data. But, in practice, the value of these services may in part be subsumed under the value of goods to which they are related, or they may be misclassified, over-reported, under-reported, or not reported at all. ${ }^{26}$ Another important question for research would therefore be to determine what proportion of separated services that are traded internationally is reported in the balance-ofpayments accounts. ${ }^{27}$ Reports prepared by Economic Consulting Services and the Office of Technology Assessment (OTA) in the United States have concluded that balance-of-payments data substantially under-report the significance of trade in separated services. ${ }^{28}$ The OTA, for example, has estimated that balance-ofpayments data in the United States may be anywhere from 45 to 100 per cent too low, depending on the definition of trade in services used and whether the 'low' or 'high' estimate is taken. ${ }^{29}$ Similar estimates would be useful for other countries.

Data on demander-located services will be more difficult to generate than data on separated services. In the former, factors have to move either physically or 'telematically'. In the case of separated factors the service may often not be recorded in the balance of payments at all. Even if (physical) factor movement is 
recorded, presumably in the 'investment income' category, it is not usually possible to distinguish between goods-related and service-related factor income. ${ }^{30}$

Insofar as one is interested in trade in services, it should be emphasized that what is needed are measures of income accruing to domestic factors of production. A measure of sales or revenues resulting from foreign direct investment in service industries will not usually be an appropriate measure of trade in services unless the services in question are separated services. For pure demander-located services, by definition, the only trade involved is of factor services. In the balance of payments of the United States income accruing to domestic factors as a result of factor movements of some kind can be found in various accounts:

(a) 'Royalties and fees from and to affiliated and unaffiliated foreigners', which includes fees for some management, professional and technical services;

(b) 'Other private services', which includes the earnings of American workers abroad; and

(c) 'Direct investment income', which measures the shares of American parent companies in the net income of their foreign affiliates, less withholding taxes plus net interest.

These accounts, however, may not reflect accurately the income accruing to domestic factors. There are various reasons for this, among which we can mention: (i) transfer pricing practices, (ii) strategic reporting of income due to the existence of differential tax rates, (iii) the existence of exchange restrictions or investment-performance requirements and (iv) variations in the degree to which firms (are forced to) reinvest earnings. ${ }^{31}$ Obviously there will exist interdependencies among these reasons. Moreover, insofar as income accruing to (separated) factors is not reported in the balance of payments at all, inaccuracies will be compounded.

Nevertheless a substantial amount of information is available regarding income accruing to American firms and to non-American firms from foreign direct investment abroad and in the United States respectively. Although incomplete, these data could be merged with balance-of-payments information, as mentioned above. But there is a problem, however, since for most other GATT member countries data on foreign direct investment are not collected systematically or at all. Thus there are major gaps in the data regarding the services associated with foreign direct investment.

Services requiring movement of demanders only appear partially in the balance of payments, primarily under the heading of 'tourism'. Data for other services of this type, such as medical and educational services, while often not reported in the balance of payments, may in fact exist. Accordingly, an effort should be made to determine the orders of magnitude involved. In the United States, for example, it has been estimated that expenditure by non-residents on health services was only 
about $\$ 100$ million in $1983 .{ }^{32}$ Revenues from overseas hospital management and consulting activities were substantially greater. $\$ 2.1$ to $\$ 3.6$ billion in 1983 . Expenditure by non-residents on educational services in the United States were estimated to be between $\$ 1.6$ and $\$ 2.4$ billion in $1983 .{ }^{33}$

Information on the existence of barriers to trade and factor movements involving services exists primarily in the United States, as noted above, but little is known about their importance and effect. Much remains to be done here, especially at the industry level.

Apart from the problems and issues discussed above, there are other considerations which will have to be addressed. Some of the more important ones are set out below. ${ }^{34}$

1. The available detail on international transactions in services is minute compared with the multitude of categories of goods identified in the existing trade and industry classifications. Because services are intangible, they are inherently more difficult to measure when compared with goods that cross national boundaries and are cleared through customs procedures. Data on many services are typically derived from periodic surveys or censuses of service industries and. therefore, it may be very burdensome and costly to achieve more detailed coverage.

2. Trade in services between domestic and foreign unaffiliated firms may not be adequately represented in balance-of-payments data. Although the United States has been making an effort to expand the coverage of data here, ${ }^{35}$ there are still major gaps. This situation is much more severe outside the United States in countries where data on foreign direct investment are limited in availability and coverage. It is also the case, as mentioned above, that the purchase of certain provider-located services (for example, education and medical care) by nonresidents may not be recorded at all. The consequence, again, is an understatement of the significance of traded services in the balance-of-payments accounts.

3. Some portion of the trade in goods reported in balance-of-payments data may actually be trade in services, but it is often not possible to separate the two because of accounting conventions within firms. Moreover. as mentioned earlier, it may be difficult to value services which are derived from tangible outputs. Unfortunately, there does not seem to be any easy way to resolve these kinds of issues without some elements of arbitrariness.

4. Some services may be reported as net rather than gross flows which will then under-state the trade involved. For countries which rely on information from their central banks regarding trade in services, this may be an important problem because cash-flow registration by banks is usually on a net basis.

5. Consistency of data on services is a problem due to differences in the types of data reported by various industries. Although, in general, revenues, sales or value added are what may be needed for purposes of comparability, these measures are 
often not reported. For example, the advertising industry reports total billings, which include costs. The insurance industry reports total insured values and total premiums, not revenues. Banks report total loans and deposits rather than the value of their intermediation services.

6. Some services may be supplied by public as well as private enterprises. Services such as education, medical care, public administration and national defence raise particularly difficult problems of valuation since, as with intra-firm transactions, there may not be any direct market analogues that can be readily used. It is for this reason that input measures commonly serve to represent the value of services in these cases. ${ }^{36}$ Thus services provided by public enterprises and government may not be measured commensurately with most private services and there may be important inter-temporal or inter-country differences depending on the private-public composition. Furthermore, governments may pursue different regulatory policies $v i s-\grave{a}$-vis services and the resulting promotion or restriction could result in national differences in the valuation and significance of particular services.

7. It may also be the case that some services are provided outside of existing market arrangements and therefore are not recorded at all. Examples include informal or 'underground' transactions which are widespread in many countries.

8. There are inconsistencies between bilateral export and import data as reported by individual countries. ${ }^{37}$ This may make it difficult to assess the importance of particular service transactions in the context of negotiations.

This discussion of data problems and gaps is by no means complete, but it provides an indication of the vast amount of effort needed to provide more basic and comprehensive information on international transactions in services. It is clear that we are a long way from the ideal data base described earlier. Nonetheless, a substantial amount of data does in fact exist and, in principle, it should be possible to take steps to merge these data in a comprehensive manner for as many countries and industries as may be feasible.

\section{Data Needs and GATT Negotiations}

While from an analytical standpoint it would be desirable to have as much information as possible, a comprehensive data base may not be required for GATT negotiations on services to be successful. It is noteworthy that relatively little quantitative information on the extent and effect of non-tariff measures existed during the Tokyo Round negotiations of 1973-79. Yet agreement was reached on codes of conduct covering several such measures. Thus there may be grounds for arguing that, so long as GATT member countries feel that there are sufficient joint gains to be made from negotiating an agreement on services, negotiations are feasible and may be fruitful. 
Many of the Tokyo Round codes did not necessitate extensive quantitative information, mainly because they did not focus on the liberalization of trade as such, but rather on the environment in which trade takes place. Thus, for example, the codes relating to Standards, Customs Valuation, Import Licensing, Subsidies and Anti-dumping all established more specific 'rules of the game'. ${ }^{38}$ This observation would also apply in large part to an 'umbrella' type of agreement covering services.

An umbrella agreement would address conceptual issues primarily. That is to say, it would presumably establish objectives and principles which would apply to the international exchange of services generally. Detailed data of the kind described above may not be necessary for an agreement of this type, just as in the case for many of the Tokyo Round codes. It should be noted, however, that lack of data may lead to limited participation in negotiations on services. If little is known regarding both the current state of the world economy and the expected effects of liberalization, a country may feel that it is not in its interest to participate. Thus negotiations may 'fail' insofar as participation might be limited to those countries which believe, rightly or wrongly, that they have something to gain.

In our view, while the availability of a comprehensive data base may not be a precondition for the successful negotiation of an umbrella agreement on services, efforts to establish such a data base should nevertheless be made. In addition to the point made in the above paragraph, the information contained in such a data base would be crucial to any evaluation of the effects of an agreement and would also be needed if more industry-specific agreements were to be sought. International organizations such as the GATT, the International Monetary Fund, the Organisation for Economic Cooperation and Development, the United Nations Conference on Trade and Development and the World Bank could play beneficial roles in the creation of a data base. Indeed, a recent proposal by the World Bank to provide staff assistance to developing countries in the Uruguay Round negotiations is laudatory, especially if efforts were to be expended in helping to create a data base that would be generally accepted.

\section{CONCLUSION}

The purpose of this article has been to identify the important analytical and policy questions that are likely to emerge in connection with services in the Uruguay Round deliberations and, in this light, to assess the need and availability of data in the United States and elsewhere.

There is a presumption on theoretical grounds that the liberalization of barriers to international trade in services and to international factor mobility would increase economic welfare by fostering greater efficiency in resource allocation, 
lowering prices and increasing the variety of options for consumers and firms. This has been a guiding principle in previous GATT rounds and there is no reason that it should not apply in the new one.

Ideally, it would be desirable to construct a global data base for services to be used as the basis for negotiations in the new GATT round. This may be difficult, however, because international transactions in services embrace both traded services and services which require the international movement of factors of production and demanders of certain specialized services. At present the data on traded services come mainly from balance-of-payments accounts and are available annually in total and by country and type. But the number of categories included in the balance-of-payments accounts is very limited and what is recorded may not be accurate.

We reviewed briefly the availability of data on services provided by foreign affiliates of American parent companies and noted that, in principle, it should be possible to merge these data with data on traded services from the balance-ofpayments accounts. The evidence suggests that services provided by the foreign affiliates of American multinational enterprises are larger in total than traded services and have a very different composition. There are some notable gaps and inconsistencies in the two types of data, but it would nonetheless be useful to attempt to combine the existing data in order to determine the orders of magnitude, composition and geographical breakdown of the international transactions in services of the United States. There is some doubt, though, whether enough data exist for the other major trading countries that could be merged in the same fashion. If not, then surely more effort must be devoted in these countries to obtain the basic data for the services provided by foreign affiliates of domestically-based parent companies.

A crucial question for the Uruguay Round negotiations is whether it will be possible to include both traded services and services which involve a foreign presence in the form of foreign direct investment and the movement of labour. In our view, the negotiating agenda for services must be broadened in this way in order to reflect the interests and potential welfare of both the major industrialized and developing countries. When it comes to the liberalization of existing barriers to traded services and the services associated with international factor mobility, it is obviously important to know what are the important barriers and what would be the effects of their reduction or elimination. Presumably the industry groups in each country would be able to identify their major concerns in terms of the domestic barriers which protect the interests of some of them and the foreign barriers which they deem to be detrimental. It will undoubtedly be extremely difficult to quantify the existing barriers affecting services which means that it may not be possible to determine the impact of liberalization in a precise manner. This ought not to stand in the way of the negotiations, however, provided the major 
participating countries can be convinced that the liberalization of barriers to international transactions in services is in their mutual interest.

If the negotiations are focussed on an umbrella agreement covering services, a comprehensive data base may not be crucial for their success. This is borne out by the experience of negotiating the various codes on non-tariff measures during the Tokyo Round deliberations. But once the Uruguay Round talks get down to specific industries and trade-offs, the need for data will become more pressing. Efforts to increase the available data on international transactions in services thus need to be greatly encouraged.

1. Helpful comments on an earlier version of this article were received from Alan V. Deardorff, participants in the workshop on Data Needs for Trade Negotiations organized by the National Bureau of Economic Research. Cambridge, Massachusetts. in September 1986 and members of the Research Seminar in International Economics at the University of Michigan. Financial assistance was provided in part by a grant from the Ford Foundation for a programme of research on trade policy at the University of Michigan.

2. Much of this section is based on Robert M. Stern and Bernard M. Hoekman. 'Conceptual Issues Relating to Services in the International Economy'. paper prepared for a workshop on Trade and Investment in Services in the Asian-Pacific Region, East-West Center, Honolulu, Hawaii, 25-26 August 1986.

3. T.P. Hill, 'On Goods and Services'. Review of Income and Wealth, New Haven. December 1977. pp. 317-18.

4. For detailed discussions, see ibid. and Stern, 'Global Dimensions and Determinants of International Trade and Investment in Services', in Stern (ed.). Trade and Investment in Services: Canada/US Perspectives (Toronto: University of Toronto Press. for the Ontario Economic Council, 1985i. and the references cited therein.

5. The term 'separated service' is used in Gary P. Sampson and Richard H. Snape, 'Identifying the lssues in Trade in Services'. The World Economy, London, June 1985.

6. See Jagdish N. Bhagwati, 'Splintering and Disembodiment of Services and Developing Nations'. The World Economy, June 1984, and Bhagwati. 'Trade in Services and Developing Countries', the Tenth Geneva Lecture, London School of Economics and Political Science. 1985.

7. Alan V. Deardorff, 'Comparative Advantage and International Trade and Investment in Services'. in Stern (ed.). op. cit.

8. This distinction is made in Task Force on Trade in Services, Background Report (Ottawa: Department of Industry. Trade and Commerce, 1982) p. 11.

9. Bhagwati, 'Splintering and Disembodiment of Services and Developing Nations', loc. cit. Professor Bhagwati's conception is that, as specialization emerges owing to economies of scale, service activities will be splintered off and become part of inter-firm transactions - as, for example, when a firm decides to purchase transport services from outside which used to be supplied internally. He views this as technically progressive. On the other hand, when goods are splintered off from services as a result of technological progress, we may be left with relatively unprogressive service industries, as conventionally measured. An example is the invention of the gramophone and records and a 'musical services' industry which now appears to be technically unprogressive.

10. These and other examples are given in Obie G. Whichard, US International Trade and Investment in Services: Data Needs and Availability. Bureau of Economic Analysis Staff Paper No. 41 (Washington: United States Department of Commerce, 1984) pp. 9-10.

11. Stern and Hoekman. op. cit. The most complete theoretical analysis of the applicability of comparative advantage to trade and factor movements involving services is to be found in Deardorff, loc. cit. Professor Deardorff's analysis demonstrates that comparative advantage may not hold in all 
cases. He constructs one example which seems to violate the principle of comparative advantage (pp. 53-68). In his 'Comments on Professor Deardorff's paper. Ronald W. Jones of the University of Rochester. takes issue with this example, although Professor Deardorff did not find his argument convincing (note 13. pp. 70-71).

12. Brian Hindley and Alasdair Smith. Comparative Advantage and Trade in Services'. The' World Economv. December 1984, pp. 377-81.

13. For a classification of service industries involved in current trade-liberalization efforts of the United States, based on motivations of foreign restrictions, see Irving B. Kravis. Services in the Domestic Economy and World Transactions: in Robert P. Inman (ed.). Managing the Service Ecomomy: Prospects and Problems (Cambridge and New York: Cambridge University Press. 1985 ). These motivations include cultural identity. financial stability, national sovereignty or security and the protection of the public from monopoly power, fraud or other undesired practices not easily discerned by consumers.

14. For a theoretical analysis. see Bhagwati. 'Why are Services Cheaper in the Poor Countries?'. Economic Journal. London. June 1984. and Bhagwati. 'Trade in Services and Developing Countries", op. cit.

15. Bhagwati. 'Splintering and Disembodiment of Services and Developing Nations'. loc' cit.

16. Bhagwati. 'Trade in Services and Developing Countries', op. cit.

17. For excellent and authoritative statements and discussion of the needs and availability of data on services. see especially the following: The International Operations of US Senice Industries: Current Data Collection and Analysis. Report prepared for the United States Departments of State and Commerce and the Office of the United States Trade Representative (Washington: Economic Consulting Services. 1981): Whichard. op. cit.: Trade in Senvices, Exports and Foreign Revenues. OTA-ITE 322 (Washington: Office of Technology Assessment. United States Congress. 1986): and Bernard Ascher and Whichard. 'Improving Services Trade Data'. in The Emergence of the Service' Economy (Geneva: Services World Forum. 1987).

18. Deardorff and Stern. The Michigan Model of World Production and Trade: Theory and 1pplications (Cambridge. Massachusetts, and London: MIT Press. 1986).

19. For a computational model of the United States and Canada. which has been used to analyze the possible effects of an American-Canadian free-trade agreement on trade and foreign direct investment. see Drusilla K. Brown and Stern. Evaluating the Impacts of US-Canadian Free Trade: What do the Multisector Trade Models Suggest?. Research Seminar in International Economics Discussion Paper No. 171 (Ann Arbor: University of Michigan. 1986).

20. See Stern. Ioc. cit.. p. 131.

21. For some developing countries - for example. Egypt. Pakistan. Portugal. Turkey and Yugoslavia - workers remittances are of great importance. In 1984 these countries received a total of $\$ 12.8$ billion in remittances. according to the International Monetary Fund 's Balance of Payments Statistic's yearbook for 1985 .

22. These data can also be broken down geographically. For a commentary on these tables, see Stern. loc. cit.. pp. 157-62.

23. A framework for merging the data is suggested in Whichard. op. cit. pp. $43-50$.

24. See Ascher and Whichard. loc: cit.. pp. 40-41.

25. For some reterences, see Stern. loc cit. pp. 157-62.

26. For example. over-reporting of banking scrvices occurs in the balance-of-payments statistic: since the data include gross interest receipts and payments of loans as well as fee-based services. Lisually. however. under-reporting of services is more likely to occur. For a discussion of the problem of measuring banking services. see Trade in Services. Exponts and Foreign Revenues. op. cit.. p. 40

27. It should be mentioned that the concept of 'separated services" is not used in the balance-ofpayments accounts. Thus separated services are to be found under various headings. For example. the category "other private services" includes separated services such as insurance not related to transport. marketing services and certain professional and technical services (for example. research).

28. The Intemational Operations of US Senvice Industries: Current Data Collection and Analisis. op. cit., and Trade in Sernices. Exports and Foreign Revenues, op. cit. 
29. Trade in Services, Exports and Foreign Revenues, op. cit., pp. 38-41.

33. In the 'benchmark' surveys of American foreign direct investment after 1982. total sales of American parent companies and majority-owned non-bank foreign affiliates are disaggregated to show sales of services separately from goods. When the two cannot be unbundled, the total sale is classified as service-related or goods-related, depending on which was the most important. See Whichard and Michael A. Shea, '1982 Benchmark Survey of US Direct Investment Abroad', Survev of Current Business, United States Department of Commerce, Washington, December 1985. While this is a substantial improvement over previous procedures, it does not cover all foreign affiliates or identify the type of services provided.

31. An attempt to supplement balance-of-payments information with firm-specific data may not be very fruitful (and would certainly be very labour intensive), given that depreciation and write-off practices, inventory valuation and capital costs will vary widely among firms. Of course, in practice it may not be possible to obtain data from the relevant firms at all. Thus (aggregated) data from official sources will usually be the best one can hope for.

32. Trade in Services, Exports and Foreign Revenues, op. cit., pp. 70-72.

33. Ibid., p. 64.

34. For a more extensive discussion, see Ascher and Whichard, loc. cit., and Trade in Services, Exports and Foreign Revenues, op. cit.

35. See Ascher and Whichard, loc. cit., pp. 39-40.

36. For a careful empirical analysis of alternative measures of these types of services, see Kravis, Alan W. Heston and Robert Summers. World Product and Income: International Comparisons of Real GDP (Baltimore: Johns Hopkins University Press, for the World Bank, 1982) pp. 133 et seq.

37. See, for example, Dorothy I. Riddle. Service-led Growth: the Role of the Service Sector in World Development (New York: Praeger, 1986) pp. 112-14 and the sources cited therein.

38. See Stern, John H. Jackson and Hoekman, An Assessment of the GATT Codes on Non-tariff Measures. Thames Essay No. 55 (Aldershot. New York and Sydney: Gower. for the Trade Policy Research Centre, 1987).

\section{$\infty$ \\ Monopoly of an Unusual Kind}

THE De Beers Central Selling Organization in London sells over 80 per cent of the world's rough gemstones and, inasmuch, is akin to both a monopoly and a producer cooperative. Harry Oppenheimer, the former chairman of De Beers Consolidated Mines, once said:

'Stability has always been recognised as essential to the diamond industry, because the price fluctuations that are accepted as normal in the case of most raw materials would be destructive of public confidence in the case of gem diamonds, which are a luxury, and the new production of diamonds each year is a comparatively small proportion of the total quantity of diamonds in jewellery held worldwide. Whether this measure of control amounts to a monopoly I would not know, but if it does it is certainly a monopoly of a most unusual kind. There is no one concerned with diamonds, whether as producer, dealer, cutter, jeweller or customer, who does not benefit from it. It protects not only the shareholders of diamond companies but also the miners they employ and the communities that are dependent on their operations. 